\title{
Review of Climate Risk Analysis in Infrastructures
}

\author{
Sara Sanchez-Matellanes ${ }^{1}$, Jorge Rodriguez-Hernandez ${ }^{1}$, \\ Daniel Castro-Fresno ${ }^{1}$, Felipe Collazos-Arias ${ }^{2}$
}

\begin{abstract}
Infrastructures are designed to have a long useful life, being the phase of exploitation the longest period. This phase requires important economic resources to ensure the optimum and safe conditions of service of the infrastructure. The objective of this paper is to review the main research projects carried out in the last years related to natural and climate risk analysis in infrastructures, trying to identify the future lines of research. The need to maintain the functionality of basic systems is clearly. Different international organizations and governments worldwide are taking measures to minimize the impacts that natural events may have on their infrastructures and population. In recent years, the number of research projects aimed at studying the evolution of climate, natural hazards and/or the resilience of infrastructures has increased greatly. 45 research projects related to the study of natural risks and infrastructures was reviewed. Society cannot afford to rebuild a 20-year-old infrastructure that has been built for a useful life of 100 years. This entails a high economic, environmental and social waste. Consequently, it is necessary to validate a methodology of analysis of climatic risks, which also facilitates the decision making on the measures to be established to increase resilience. Copyright (c) 2018 Praise Worthy Prize S.r.l. - All rights reserved.
\end{abstract}

Keywords: Climate Change, Infrastructure, Project, Resilience, Risk, Tool

\section{Introduction}

The objective of this paper is to review the main research projects carried out in the last years and Government plans related to natural and climate risk analysis in infrastructures, trying to identify the future lines of research.

\section{I.1. Risk}

Risk is the existing uncertainty of achieving defined objectives, which is generally related to the likelihood of an event occurring and the magnitude of its consequences [1], it being possible to quantify the damage caused by the risk. Vulnerability to separate threats does not pose a hazard, but if they come together, the probability of a disaster occurring is greater [2].

Risks can affect the achievement of the stated objectives, which can translate directly or indirectly into an economic and/or environmental cost and/or human casualty. Infrastructures have a life cycle with five main phases: planning, design, construction, operation and dismantling [3]. Integral risk management of an infrastructure can be divided into two stages:

- Project management: when the infrastructure is an idea being planned, designed and constructed.

- Exploitation management: when the infrastructure itself is a real element under exploitation (maintenance, conservation, rehabilitation) till its end of life (dismantling and/or substitution).
In relation to project risk management the main points are: planning, risk identification, risk analysis, risk response planning and finally, control of risks. [4], [5].

Despite the existing management models in relation to the construction sector, none of them ensures adequate decision making to achieve the established objectives.

On the one hand, taking into account the legislation and standards in force in different developed countries, risks related to labor accidents and environmental impact related to infrastructure projects have been of great interest. The risk analysis methodologies developed within the construction sector have had the main objective of reducing the large number of labor accidents and improving environmental evaluations. On the other hand, considering the voluntary actions, construction is a sector whose activity causes damage to the environment, which has motivated a movement related to sustainability [6]. Taking into account the environmental and economic impact on the society generated by the construction sector, the sector tries to minimize the damage produced by voluntary sustainability initiatives [7] that minimize and compensate the risks.

Infrastructures are designed and built to have a long useful life. Consequently, the phase of exploitation and maintenance is the longest period in the life cycle of an infrastructure. This phase requires important economic resources to ensure the optimum and safe conditions of service of the infrastructure. The management of this phase involves minimizing or eliminating the uncertainty to achieve the best results [8]. 
Usually, natural hazards (mainly earthquakes, volcanos and slides) are considered in both the infrastructure design and operation. However, this is not the case of climate risks (see Table I).

TABLE I

RISKS ASSOCIATED WITH EACH PHASE

\begin{tabular}{|c|c|c|c|c|}
\hline Risks & $\begin{array}{l}\text { Labor } \\
\text { accidents }\end{array}$ & $\begin{array}{c}\text { Environmental } \\
\text { impacts }\end{array}$ & $\begin{array}{l}\text { Natural } \\
\text { hazards }\end{array}$ & $\begin{array}{l}\text { Climate } \\
\text { Change } \\
\text { effects }\end{array}$ \\
\hline Planning & $\sqrt{ }$ & $\sqrt{ }$ & $\sqrt{ }$ & $\mathrm{X}$ \\
\hline Design & $\sqrt{ }$ & $\sqrt{ }$ & $\sqrt{ }$ & $\mathrm{X}$ \\
\hline Construction & $\sqrt{ }$ & $\sqrt{ }$ & $\sqrt{ }$ & $\mathrm{X}$ \\
\hline Operation & $\sqrt{ }$ & $\sqrt{ }$ & $\sqrt{ }$ & $\mathrm{X}$ \\
\hline End of life & $\sqrt{ }$ & $\sqrt{ }$ & $\sqrt{ }$ & $\mathrm{X}$ \\
\hline
\end{tabular}

Unfortunately, taking into account Climate Change (CC) effects, the huge amount of infrastructure already built at the global level is under continuous and increasing risk. Specifically, the climatic conditions may have changed giving rise to a risk not studied or evaluated previously, and it is in the operation phase that there has been an increase in the number and intensity of climate risks, the consequences of which are costly [9][12].

Moreover, research and proposals regarding risk analysis methodologies for the operation phase are scarce. As discussed in [13], of the 427 publications related to security in the construction sector, only 5 are focused on the operation phase.

\section{I.2. Resilience}

Since 1970, the number of natural disasters on all continents has continued to increase; causing high material and/or environmental costs and loss of human lives. It is necessary to maintain the functionality of basic systems or to ensure their recovery in the shortest time possible in order to limit damage or loss of functionality due to natural hazards [14].

In 2005, Hurricane Katrina took place and caused the rupture of the levees of New Orleans, causing the system to collapse and a large number of deaths. Hurricane Sandy in 2012 reached a diameter of $1,900 \mathrm{~km}$, causing damage in Colombia, Venezuela, Haiti, the Dominican Republic, Cuba, Jamaica, the United States and Canada among other countries. Taking into account the material, environmental and personal damage caused by these two hurricanes, urban resilience has become a priority in many countries. For example, after Hurricane Sandy, an international workshop on risk in cities was held in 2013 in the province of Santiago de Cuba. The study and integration of the increase in climatological events, the increase in temperature and the risk of rising sea levels was proposed, discussing the strengthening of urban resilience and considering Santiago de Cuba a reference with the passage of Hurricane Sandy [2].

Later, worldwide in 2014, 980 natural catastrophes with 7,700 deaths occurred and in 2015, there were 1,060 catastrophes with 23,000 deaths. Losses due to natural disasters are increasing in many countries, and include earthquakes in Italy, Indonesia, Taiwan and Japan, or the one in Nepal in 2015, which killed 9,000 people [15].

Natural hazards include those associated with CC, which in recent years are increasing according to The International Disaster Database [16]. Extreme heat waves, like the ones in 2014 and 2015 with 4,900 deaths in India, Pakistan and Europe [15], and other extreme events, such as floods in France, Sudan and Ethiopia, droughts in Bolivia, Vietnam and China, and even fires in Australia, have been found to be related to $\mathrm{CC}$.

In $65 \%$ of the cases studied by the American Meteorological Society, CC has influenced the variation of intensity or frequency of these extreme climate events [17]. For example, CC has increased the likelihood of some events such as the August 2016 floods in Louisiana by a factor of 1.4, floods in France in May / June 2016 by a factor of 2.3 (Seine) and 2.0 (Loire) and heat waves that affected Europe in July 2015 by a factor of at least 2 . [15]. Consequently, climate risks are an important and increasing part of natural risks.

Global temperatures are rising, precipitation is changing, glaciers are melting, causing rising mean sea levels, rising heat waves and flooding among other changes being detected globally [18]. As a result, our infrastructures are being exposed to new risks, mainly during the exploitation phase, associated with the effects of CC. Therefore, an adaptation plan would be of great importance, in which investments to increase infrastructure resilience to negative impacts should be considered [19].

Resilience is "the ability of a system, community or society exposed to threats to resist, absorb, accommodate and recover from the effects of a (materialized) threat in a timely and efficient manner, including the preservation and restoration of its structures and basic functions". In addition, at the level of social organization, resilience "is determined by the degree to which the community has the necessary resources and is able to organize, both before and during times of need" [20]. Resilience, in relation to infrastructures, is their ability to absorb disturbances and maintain their basic function and structural capacity. According to the UK government, resilience is the combination of four components: resilience, reliability, adaptability and response and recovery, as reflected in the "Summary of the Sector Resilience Plans" plan of 2013.

Natural disasters have highlighted the importance of considering infrastructure resilience at the design stage [21]. Infrastructures should not only be designed to guarantee minimum safety measures over their life span, but also to withstand all risks associated with natural disasters. Increased resilience and lifespan of infrastructures can be achieved by applying the best available materials and technology, using innovative inspection and maintenance strategies [22]. Engineers need to know the risks that may have a low probability, but which can have a great impact on the infrastructure, with the aim of improving the management of the consequences of this type of risk [23]. 
Different natural events that have caused great damage in society have increased the importance of considering resilience to natural events in the sustainable design practices of structures [7]. Therefore, increased resilience to such events is of great interest to society.

Supporting or reducing the time of recovery of an infrastructure after natural risks will facilitate the availability of media that provide assistance to the affected population. The cost of rebuilding a damaged infrastructure can be a great economic investment.

Taking precautionary measures to avoid or mitigate this damage may lead to less investment in infrastructure rehabilitation [9]-[12].

Sustainability in the construction sector is related to activities that promote the minimization of environmental impacts generated by the activity, taking measures such as reducing the consumption of raw materials or reducing the energy consumption, among others. These measures are also associated with the resilience of the infrastructure because, if during the exploitation phase it is necessary to carry out emergency actions to maintain the infrastructure in service, each of these actions generates new environmental damage.

Therefore, the reduction of this type of actions, increasing the resilience of the infrastructure entails a necessary reduction of environmental damage and supposes a monetary saving in the long term, minimizing the risk level.

\section{International Strategies}

Different international organizations and governments worldwide are taking measures to reduce the impacts that natural, and specifically climate risks, may have on their infrastructures and population. Among the Sustainable Development Goals (SDGs) set out in 2015 by the United Nations Development Program, "Goal 9: Industry, innovation, infrastructure" highlights the importance of carrying out the construction of resilient infrastructures [24].

The World Bank, reference [25], highlighted the increase of the costs generated by natural risks.

Specifically, the World Bank seeks to improve urban resilience in developing countries, because the increase in natural disasters and other social risks represents the greatest risk for fast growing cities [26]. The World Bank is currently operating in some developing countries, for example in Africa, where the construction of resilient infrastructures will be indispensable for the economic development of the country.

Other organizations such as FAO and OECD, reference [27], also reflect the initiatives in different countries regarding adaptation measures to $\mathrm{CC}$ to increase resilience, but mainly in the agriculture sector.

While it is true that these organizations take the importance of infrastructures for the development of the least developed countries into account, the main actions are directly related to human health and agriculture, with infrastructures still remaining in the background.

\section{II.1. The United States}

The United States Environmental Protection Agency (EPA) since 2011 has been publishing documents regarding how $\mathrm{CC}$ affects human health and the environment.

The American Meteorological Society also analyzes every year the natural events worldwide that have caused damage, analyzing their costs and effect on to the population.

Apart from this, there are numerous organizations in the United States that conduct studies related to the impact of $\mathrm{CC}$ on different sectors, including infrastructure. In the Policy Statement on CC Adaptation of June 2014, one of the plans is a program to encourage climate-resilience investments. Nowadays, the United States Global Change Research Program includes 13 agencies to coordinate climate-related work.

One of them, the National Climate Assessment, summarizes the impacts of $\mathrm{CC}$ in the country and those which are expected in the future.

In addition, they have a tool, the Climate Resilience Toolkit, with which it is possible to observe the risks and measures taken against $\mathrm{CC}$ in different places in the United States [28].

\section{II.2. Europe}

The European Commission publishes on its website the consequences of $\mathrm{CC}$, highlighting the increase in the frequency of floods and adverse weather events among others. Measures to minimize the risks associated with $\mathrm{CC}$ are being established in each of the European countries, including measures to strengthen infrastructures and minimize harm to the population.

For example, Germany, in 2008, compiled in its "German Strategy for Adaptation to $\mathrm{CC}$ " the climatic risks that affect its infrastructures and the need to establish measures for their minimization. France, in 2011, published its "National Plan for Adaptation to Climate Change" which contemplates the need to adapt infrastructures to $\mathrm{CC}$.

Austria, in 2012, established strategies in each sector including infrastructures to avoid adverse effects caused by CC. In addition, the UK Government in 2014 in its "National Infrastructure Plan" stresses the need to achieve within its projects the specific objectives of resilience and sustainability of infrastructures. The aim is to ensure an infrastructure network that improves the country's progress by improving the country's resilience, among other measures.

Also in 2014, Finland approved the National Climate Change Adaptation Plan 2022 to help mitigate the consequences of $\mathrm{CC}$ in different sectors. And Spain within its "National Plan for Adaptation to Climate Change. Third work program 2014-2020 ", includes the study" Necessity to adapt to CC in the trunk network of transport infrastructure in Spain ", which analyzes the effects and consequences of $\mathrm{CC}$ on infrastructure in service [29]. 


\section{II.3. Others}

Some countries have established strategies to improve resilience to $\mathrm{CC}$. Measures and lines of action are being taken in the face of climate change, either with countryspecific studies or with the assistance of different organizations such as the World Bank or the United Nations Development Program (UNDP).

The UNDP participated in relation to $\mathrm{CC}$ in different countries; such as Uruguay, with the "Climate Plan of the Montevideo Metropolitan Region" in 2012, whose main objective is to reduce greenhouse gas emissions and the study of vulnerabilities of the city. In Afghanistan, with the "Border Management in North Afghanistan" project (BOMNAF), which has helped build new infrastructure to create a stronger country, as published in September 2016 in the document "Bridging Bridges in Afghanistan, Regional Cooperation and Border Management to Promote Peace and Development." Or in Bosnia and Herzegovina, where it is implementing a flood early warning system, published in September 2016 in the document "Flood Alarm Systems in Bosnia and Herzegovina". Finally, the case of Bhutan is remarkable, one of the most vulnerable countries to health risks due to its climate, where $15 \%$ of the country's morbidity is due to diarrheal diseases. The main measurements there are focused on improving the health of people, as is included in the document "Climate Change. Bhutan responds" of September 2016.

The United States Agency for International Development (USAID) is acting in different nations worldwide; in countries in Africa, Asia or Eurasia, like Pakistan and Afghanistan among others. Its main task is working for the eradication of extreme poverty, the health of the people or improvement in agriculture.

Moreover, the Japan International Cooperation Agency (JICA) has participated in the Horn of Africa to increase the drought resilience of the populations of Northern Kenya, published in its annual report "JICA 2015 Japan International Cooperation Agency ".

Mexico City in 2008 elaborated the "Climate Action Program of Mexico City 2008-2012", whose main objectives are the reduction of greenhouse gas emissions and measures to adapt the city to CC. Later, in November 2016, Mexico City established that its main threat is the possible relapse of millions of families into poverty, which has promoted strategies for social development and the construction of resilient societies.

Chile, in December 2014, published the "National Plan for Adaptation to Climate Change" with cooperation from Germany, prepared under the National Action Plan on Climate Change. This reflects the expected impacts in the country and the lines of action and monitoring in the different sectors to address the risks related to $\mathrm{CC}$ and thus improve resilience in each sector. More in detail, the study about the change in the microclimates applied to the city of Concepción highlights the important impact on human communities [30].

Another example is Colombia, where they plan to protect ecosystems and communities against the risks of floods and droughts through family gardens, or Bolivia, where an agreement for the elimination of malaria has been signed in the framework of the adaptation to $\mathrm{CC}$ effects.

In Africa, an example is Rwanda, whose government in 2011 published the strategy for adaptation to CC, "The Green Growth and Climate Resilience National Strategy for Climate Change and Low Carbon Development", giving priority to the reduction of the use of coal and measures to reduce risks in agriculture and society.

Australia published the document "National Climate Resilience and Adaptation Strategy" in 2015, noting that the cost of damage associated with natural disasters in 2012 amounted to $\$ 6$ trillion and by 2050 is expected to cost 23 billion dollars. It includes the strategy of adapting and improving resilience to the risks associated with $\mathrm{CC}$.

The website of the ACT Government shows the initiatives they have established to study the climate's effect in their country and to analyze the measures and strategies to be adopted. Some related specific studies are the analysis of the vulnerability of electricity infrastructures to the events of CC in China and Japan carried out [31] or the study of the adaptation capacity of institutions in Canada, Argentina and Chile to droughts and floods [32]. All of this shows the great concern of the different administrations and organizations about the risks generated by $\mathrm{CC}$, the need to carry out studies to forecast the evolution of the climate and to adopt measures which reduce the consequences of the risks detected in the population, environment or infrastructure.

However, as expected, much of the work done in nondeveloped countries focuses on improving the health of the population and on increasing the resilience of agriculture to $\mathrm{CC}$, which are the main priorities for these communities. Meanwhile, in the developed countries, the importance of considering natural risks, and specifically new climate risks, is paramount in the consecution of urban and infrastructure adaptation to the $\mathrm{CC}$ and resilience.

\section{Research Projects}

In recent years the number of research projects aimed at studying the evolution of climate, natural hazards and/or the resilience of infrastructures and urban areas to unwanted natural events, has undergone a large increase.

After analyzing the international strategies toward climate risks, it has been decided to limit the search for research projects and methodologies related with climate risks in infrastructures to the United States and Europe.

A selection of 45 research projects related to the study of natural risks and infrastructures was reviewed. The analysis was done based on the objective pursued in the main line of research of each of the projects. The first of these projects finished in 2006 and $43 \%$ of the localized projects were developed between 2014 and 2016.

Regarding climate risks, $24 \%$ of the reviewed projects focus on their effect on cities and $14 \%$ on the infrastructures. 


\section{III.1. Non-Climate Natural Risks}

The non-climate natural risks are mainly related with the geological conditions and they have been considered previously to the CC effects in many countries. The US, Japan, Italy or Chile, for example, are countries used to taking into account disaster risks related to earthquakes and/or volcanoes (see Table II).

TABLE II

MAIN PROJECTS RELATED TO NON-CLIMATE NATURAL RISKS

\begin{tabular}{cllll}
\hline \hline Year & \multicolumn{1}{c}{ Name } & Acronym & \multicolumn{1}{c}{ Source } \\
\hline 2006 & $\begin{array}{l}\text { Risks from } \\
\text { Earthquake DAmage } \\
\text { to Roadway Systems. }\end{array}$ & REDARS & {$[33]$} \\
2013 & $\begin{array}{l}\text { Mitigate and assess } \\
\text { risk from volcanic } \\
\text { impact on terrain and } \\
\text { human activities. }\end{array}$ & & MiaVita & $\begin{array}{l}\text { http://miavita.brgm } \\
\text { fr/consortium/page } \\
\text { s/consortium.aspx }\end{array}$ \\
2014 & $\begin{array}{l}\text { Strategies and tools } \\
\text { for Real time }\end{array}$ & REAKT & $\begin{array}{l}\text { http://www.reaktpr } \\
\text { oject.eu/ }\end{array}$ \\
& $\begin{array}{l}\text { EArthquake risK } \\
\text { reduction. }\end{array}$ & & \\
LAndslide Modelling \\
and tools for \\
vulnerability \\
assessment \\
$\begin{array}{l}\text { Preparedness } \\
\text { REcovery and } \\
\text { management }\end{array}$
\end{tabular}

Within the project LAMPRE, the Landslide-Road Impact Model (LRIM) application has been developed to analyze potential landslides that can affect roads. This is an application of great interest to consider for the analysis of possible risks associated with the instability of slopes.

This is a natural risk apparently independent of CC but, due to the influence of rainfall in geotechnical engineering, slope instability could also have been considered a climatic risk.

\section{III.2. Climate Risks}

Climate risks were also considered before CC confirmation in certain regions of the world with usual heatwaves, snowstorms, rainstorms, tornados, hurricanes or typhoons. However, $\mathrm{CC}$ effects in the known patterns and the new climate risks made it necessary to invest important resources in doing research on how climate is affecting urban areas and infrastructures (see Table III).

Considering roads, IRWIN is a project aimed at improving the management of winter conditions taking into account the new climatological scenarios foreseen in the future. Another study of great interest to take into account for the construction of future projects is the CliPDaR (Climate Projection Data for Roads) project, which shows the increased intensity of risks associated with CC. This project is of great importance to know the forecast of $\mathrm{CC}$ in Europe, since it will offer relevant data to know the areas likely to be affected by $\mathrm{CC}$.

Within the projects that study climate risk in maritime areas, THESEUS is of great interest in proposing possible coastal solutions because of the risks associated with $\mathrm{CC}$ that can affect coastal infrastructures.

TABLE III

Main Projects Related To Climate Change And Built ENVIRONMENT

\begin{tabular}{|c|c|c|c|}
\hline Year & Name & Acronym & Source \\
\hline 2009 & $\begin{array}{l}\text { Improved local } \\
\text { Winter index to } \\
\text { assess maintenance } \\
\text { needs and } \\
\text { adaptation costs in } \\
\text { climate change } \\
\text { scenarios. }\end{array}$ & IRWIN & $\begin{array}{l}{[34] ;} \\
\text { goo.gl/Lp3AjO }\end{array}$ \\
\hline 2012 & $\begin{array}{l}\text { Effects of climate } \\
\text { change on the } \\
\text { inland waterway } \\
\text { transport network. }\end{array}$ & ECCONET & {$[35]$} \\
\hline 2013 & $\begin{array}{l}\text { Innovative } \\
\text { technologies for } \\
\text { safer European } \\
\text { coasts in a } \\
\text { changing climate. }\end{array}$ & THESEUS & $\begin{array}{l}\text { http://www.theseus } \\
\text { project.eu/ }\end{array}$ \\
\hline 2014 & $\begin{array}{l}\text { Climate projection } \\
\text { data base for roads. }\end{array}$ & CliPDaR & $\begin{array}{l}{[36] ;} \\
\text { http://climod.eu/pr } \\
\text { ojects/clipdar }\end{array}$ \\
\hline
\end{tabular}

Some projects specifically analyze the risks associated with rainfall, with the possible damage that the change in the rainfall regime can cause in the infrastructures and cities in the future (see Table IV).

TABLE IV

MAIN PROJECTS RELATED TO RAINFALL RISKS

\begin{tabular}{|c|c|c|c|}
\hline Year & Name & Acronym & Source \\
\hline 2010 & $\begin{array}{l}\text { Storm Water } \\
\text { prevention -Methods } \\
\text { to Predict damage } \\
\text { from the water } \\
\text { stream in and near } \\
\text { road pavements in } \\
\text { lowland areas }\end{array}$ & SWAMP & goo.gl/TPZkJS \\
\hline 2011 & $\begin{array}{l}\text { Technologies for the } \\
\text { cost-effective Flood } \\
\text { Protection of the } \\
\text { Built Environment }\end{array}$ & FloodProBE & $\begin{array}{l}\text { http://www.floodp } \\
\text { robe.eu/ }\end{array}$ \\
\hline 2013 & $\begin{array}{l}\text { The Smarter } \\
\text { Resilience, Tools, } \\
\text { Technologies and } \\
\text { Systems }\end{array}$ & SMARTeST & $\begin{array}{l}\text { http://www.smartfl } \\
\text { oodprotection.com } \\
\text { /the-smartest- } \\
\text { project-2/ }\end{array}$ \\
\hline 2013 & $\begin{array}{l}\text { Collaborative } \\
\text { Research on Flood } \\
\text { Resilience in Urban } \\
\text { areas }\end{array}$ & CORFU & $\begin{array}{c}\text { http://www.corfu7. } \\
\text { eu/results/ }\end{array}$ \\
\hline 2016 & $\begin{array}{l}\text { STrengthening And } \\
\text { Redesigning } \\
\text { European FLOOD } \\
\text { risk practices: } \\
\text { Towards appropriate } \\
\text { and resilient flood } \\
\text { risk governance } \\
\text { arrangements }\end{array}$ & $\begin{array}{l}\text { STAR- } \\
\text { FLOOD }\end{array}$ & $\begin{array}{c}\text { http://www.starflo } \\
\text { od.eu/ }\end{array}$ \\
\hline 2016 & $\begin{array}{l}\text { An Agent- Based } \\
\text { Disaster Response } \\
\text { Inference Model for } \\
\text { Assessment of } \\
\text { Transportation Risk } \\
\text { under Extreme } \\
\text { Events }\end{array}$ & - & [37] \\
\hline
\end{tabular}


The Collaborative Research on Flood Resilience in Urban Areas (CORFU) is aimed at analyzing the latest methodologies developed to study urban floods, avoiding possible duplications and improving management in urban areas in the face of future flood events.

Some other projects mainly analyzed the cost of the damage caused by CC (see Table V). These projects highlight the importance of increasing the resilience of infrastructures and urban areas to this type of undesired events, with the objective of reducing the costs of the consequences.

TABLE V

Main Projects Related To The STUdy Or AsSEsSment Of The COST ASSOCIATED With Climate RisKS

\begin{tabular}{|c|c|c|c|}
\hline Year & Name & Acronym & Source \\
\hline 2008 & Resilience United States & ResilUS & [38], [39] \\
\hline 2009 & $\begin{array}{l}\text { Costing Asset Protection for } \\
\text { Transportation Agencies }\end{array}$ & CAPTA & [40], [41] \\
\hline 2012 & $\begin{array}{c}\text { Weather extremes: } \\
\text { assessment of impacts on } \\
\text { transport systems and } \\
\text { hazards for European } \\
\text { regions }\end{array}$ & WEATHER & $\begin{array}{l}\text { http://ww } \\
\text { w.weather- } \\
\text { project.eu/ } \\
\text { weather/in } \\
\text { dex.php }\end{array}$ \\
\hline 2012 & $\begin{array}{l}\text { Extreme weather impacts on } \\
\text { European networks of } \\
\text { transport }\end{array}$ & EWENT & {$[42]$} \\
\hline 2017 & $\begin{array}{c}\text { Hazus-MH } 4.0- \\
\text { Earthquake, Wind and } \\
\text { Flood }\end{array}$ & HAZUS® & [43] \\
\hline 2008 & Resilience United States & ResilUS & {$[38],[39]$} \\
\hline
\end{tabular}

HAZUS $®$ has been developed in the United States by the Federal Emergency Management Agency (FEMA) since 1997 and it is a GIS-based natural hazard management tool that enables the determination of the losses caused by multi-hazards: floods, hurricanes, earthquakes and tsunamis [43]. Meanwhile Resilience United States (ResilUS) is a model that enables the study of loss and recovery before an extreme event in terms of socioeconomic agents, neighbourhoods and communities associated with natural hazards [38], [39].

\section{III.2.1. Urban Areas}

Cities are growing in population as well as in their urban infrastructures: transport, energy supply and other urban services that a population needs. The projects shown in Table VI seek to study the damage that CC can pose specifically for urban services.

CLUVA is a European project for the development of methods and knowledge to improve the management of climate risks in Africa. The objective is to reduce vulnerability and improve communities' survival and resilience to climate change. The project focuses on various cities in Africa and analyzes vulnerability to climate change, resilience, risk management and adaptation strategies.

HAZUR ${ }^{\circledR}$ is software developed by the company Opticits located in Barcelona, which has been applied in several places in Europe. It is designed and focused on urban areas, considering the framework of the 100 Resilient Cities. It enables the analysis of the effects that a disturbance or environmental damage would cause in a population, including an analysis of the effects on the different infrastructures (public transport, water network, electrical lines, etc.) of a city.

TABLE VI

MaIN PROJECTS AsSOCIATED WITH NATURAL HAZARDS AFFECTING URBAN AREAS

\begin{tabular}{|c|c|c|c|}
\hline Year & Name & Acronym & Source \\
\hline 2013 & $\begin{array}{c}\text { Climate change and } \\
\text { Urban Vulnerability } \\
\text { in Africa }\end{array}$ & CLUVA & $\begin{array}{c}\text { http://www.cluva.e } \\
\text { u/index.php?option } \\
=\text { com_content\&vie } \\
\text { w=frontpage\&Itemi } \\
\mathrm{d}=1\end{array}$ \\
\hline 2013 & $\begin{array}{l}\text { Metrics and } \\
\text { Performance } \\
\text { Response Functions } \\
\text { for Assessment of } \\
\text { Resilience of Urban } \\
\text { Infrastructure } \\
\text { Systems }\end{array}$ & - & [44] \\
\hline 2014 & $\begin{array}{l}\text { A GIS-based } \\
\text { Performance } \\
\text { Measurement System } \\
\text { for Assessing } \\
\text { Transportation } \\
\text { Sustainability and } \\
\text { Community } \\
\text { Livability }\end{array}$ & - & [45] \\
\hline 2014 & $\begin{array}{l}\text { HAZUR Resilient } \\
\text { Systems }\end{array}$ & HAZUR® & $\begin{array}{l}\text { Opticits, Opticits } \\
\text { towards resiliencie. } \\
\text { http://opticits.com/ }\end{array}$ \\
\hline 2014 & $\begin{array}{l}\text { The Sustainable } \\
\text { Infrastructure for } \\
\text { Resilient Urban } \\
\text { Environments }\end{array}$ & SIRUE & $\begin{array}{c}\text { http://cordis.europa. } \\
\text { eu/project/rcn/1015 } \\
\text { 68_en.html }\end{array}$ \\
\hline 2014 & $\begin{array}{l}\text { Low-disturbance } \\
\text { sustainable urban } \\
\text { construction }\end{array}$ & $\begin{array}{c}\text { PANTUR } \\
\text { A }\end{array}$ & $\begin{array}{c}\text { http://www.pantura- } \\
\text { project.eu/Main.asp } \\
\text { x?uri=20,26,9 }\end{array}$ \\
\hline 2015 & $\begin{array}{c}\text { Analyzing } \\
\text { Willingness to } \\
\text { Improve the } \\
\text { Resiliency of New } \\
\text { York City's } \\
\text { Transportation } \\
\text { System }\end{array}$ & - & [46] \\
\hline 2018 & $\begin{array}{l}\text { Climate Resilient } \\
\text { Cities and } \\
\text { Infrastructures } \\
\end{array}$ & RESIN & $\begin{array}{l}\text { http://www.resin- } \\
\text { cities.eu/home/ }\end{array}$ \\
\hline
\end{tabular}

\section{III.2.2. Infrastructures}

Infrastructures connect cities and are indispensable for the development of the population. Most of the investment in research has been dedicated to projects of great importance to knowing the damage that $\mathrm{CC}$ can cause to infrastructures, as well as the measurements that can be applied to reduce the negative effects (see Table VII).

INFRARISK aims to identify natural hazards with low frequency, which have the potential to have extreme impact on critical infrastructure. It uses an integrated approach, taking into account the interdependence of infrastructure networks, the correlation of natural 
hazards, cascading hazards and cascading effects, and spatial and temporal vulnerability.

TABLE VII

Main Projects Related To NATURAl HaZARdS AFFECTING INFRASTRUCTURE

\begin{tabular}{|c|c|c|c|}
\hline Year & Name & Acronym & Source \\
\hline 2010 & $\begin{array}{l}\text { Pavement Performance } \\
\text { and Remediation } \\
\text { Requirements following } \\
\text { Climate Change }\end{array}$ & $\mathrm{P} 2 \mathrm{R} 2 \mathrm{C} 2$ & goo.gl/uYGPRl \\
\hline 2015 & $\begin{array}{c}\text { Data-Driven Highway } \\
\text { Infrastructure } \\
\text { Resilience }\end{array}$ & - & {$[47]$} \\
\hline 2016 & $\begin{array}{l}\text { Life Cycle Engineering } \\
\text { approach to develop a } \\
\text { novel EU-harmonized } \\
\text { sustainability } \\
\text { certification system for } \\
\text { cost-effective, safer and } \\
\text { greener road } \\
\text { infrastructures }\end{array}$ & $\begin{array}{l}\text { LCE4RO } \\
\text { ADS }\end{array}$ & $\begin{array}{c}\text { http://ecolabelpro } \\
\text { ject.eu/workpack } \\
\text { ages/ }\end{array}$ \\
\hline 2016 & $\begin{array}{c}\text { Novel Indicators for } \\
\text { identifying critical } \\
\text { INFRAstructure at } \\
\text { RISK from natural } \\
\text { hazards }\end{array}$ & $\begin{array}{l}\text { INFRARI } \\
\text { SK }\end{array}$ & $\begin{array}{l}\text { https://www.infra } \\
\text { risk-fp7.eu/ }\end{array}$ \\
\hline 2016 & $\begin{array}{c}\text { Bottom-Up Climate } \\
\text { Adaptation Strategies } \\
\text { Towards a Sustainable } \\
\text { Europe }\end{array}$ & BASE & $\begin{array}{c}\text { http://base- } \\
\text { adaptation.eu/ }\end{array}$ \\
\hline 2016 & $\begin{array}{l}\text { Harmonized approach } \\
\text { to stress tests for critical } \\
\text { infrastructures exposed } \\
\text { to natural hazards }\end{array}$ & STREST & $\begin{array}{c}\text { http://www.strest } \\
- \\
\text { eu.org/opencms/ } \\
\text { opencms/ }\end{array}$ \\
\hline 2017 & $\begin{array}{c}\text { Risk and Failure } \\
\text { Resilience } \\
\text { Quantification of } \\
\text { Interdependent } \\
\text { Transportation Systems }\end{array}$ & - & $\begin{array}{c}\text { http://www.ctre.i } \\
\text { astate.edu/resear } \\
\text { ch/detail.cfm?pro } \\
\text { jectID=- } \\
1754808215\end{array}$ \\
\hline 2017 & $\begin{array}{l}\text { The Critical } \\
\text { Infrastructure } \\
\text { Preparedness and } \\
\text { Resilience Research } \\
\text { Network }\end{array}$ & CIPRNet & $\begin{array}{l}\text { https://www.cipr } \\
\text { net.eu/summary. } \\
\text { html }\end{array}$ \\
\hline 2017 & $\begin{array}{l}\text { Impact of extreme } \\
\text { weather on critical } \\
\text { infrastructure }\end{array}$ & INTACT & $\begin{array}{c}\text { http://www.intact } \\
- \\
\text { project.eu/index. } \\
\text { cfm }\end{array}$ \\
\hline 2018 & $\begin{array}{c}\text { A panEuropean } \\
\text { framework for } \\
\text { strengthening Critical } \\
\text { Infrastructure resilience } \\
\text { to climate change }\end{array}$ & $\begin{array}{c}\text { EU- } \\
\text { CICLE }\end{array}$ & $\begin{array}{c}\text { http://cordis.euro } \\
\text { pa.eu/project/rcn/ } \\
\text { 196896_en.html }\end{array}$ \\
\hline 2018 & $\begin{array}{c}\text { Realising European } \\
\text { ReSiliencE for CritIcaL } \\
\text { INfraStructure }\end{array}$ & $\begin{array}{l}\text { RESILEN } \\
\mathrm{S}\end{array}$ & $\begin{array}{c}\text { http://cordis.euro } \\
\text { pa.eu/project/rcn/ } \\
\text { 194842_en.html }\end{array}$ \\
\hline
\end{tabular}

\section{Climate Risk Analysis in Roads}

In view of the knowledge of the climatic risks and the damage they cause, some research projects focusing on climate risk analysis in roads have been selected with the objective of reviewing the main tools for analysis of climatic risks in infrastructures.

\section{IV.1. Main Methodologies}

Table VIII summarizes the main references found about current climate risk analysis in infrastructures.

Other projects such as the HyRiM (Hybrid Risk Management for Utility Providers) are excluded from this study because their main objective is to identify and evaluate the security risks in the service infrastructure networks (gas, electricity, etc.) that are interconnected, all in order to provide a basis for new protection and prevention mechanisms. Also excluded from this study are those projects focused on the management of recovery work following an unexpected climate event such as COBACORE (COmmunity-BAsed COmprehensive REcovery) or CRISMA (Modeling crisis management for improved action and preparedness); nor do we consider projects analyzing cascade effects such as FORTRESS (Foresight Tools for Responding to cascading effects in a crisis), CascEff (Modeling of dependencies and cascading effects for emergency management in crisis situations) or PLACARD (PLAtform for Climate Adaptation and Risk reDuction) which aims to develop a platform to strengthen communities.

TABLE VIII

Main Projects Related To The DeVElopment OF NATURAL Risk ANALYSIS METHODOLOGIES

\begin{tabular}{|c|c|c|c|}
\hline \multicolumn{4}{|c|}{ ANALYSIS METHODOLOGIES } \\
\hline Year & Name & Acronym & Source \\
\hline 2010 & $\begin{array}{c}\text { Risk Management for } \\
\text { Roads in a Changing } \\
\text { Climate }\end{array}$ & RIMAROCC & $\begin{array}{c}\text { goo.gl/xewT } \\
\mathrm{Sg}\end{array}$ \\
\hline 2010 & $\begin{array}{c}\text { Towards development of } \\
\text { a risk management } \\
\text { approach }\end{array}$ & - & {$[48]$} \\
\hline 2011 & $\begin{array}{c}\text { Probabilistic Risk } \\
\text { Assesment Program }\end{array}$ & CAPRA & $\begin{array}{l}\text { Los Andes } \\
\text { University, } \\
\text { http://www.e } \\
\text { capra.org/es/ } \\
\text { software }\end{array}$ \\
\hline 2014 & $\begin{array}{l}\text { Management or weather } \\
\text { events in the transport } \\
\text { system }\end{array}$ & MOWE-IT & $\begin{array}{l}\text { http://www. } \\
\text { mowe-it.eu/ }\end{array}$ \\
\hline 2015 & $\begin{array}{l}\text { Roads for today, Adapted } \\
\text { for tomorrow }\end{array}$ & ROADAPT & $\begin{array}{c}\text { goo.gl/u21U } \\
\text { FX }\end{array}$ \\
\hline 2016 & $\begin{array}{l}\text { Methodologies and tools } \\
\text { for Risk Assessment and } \\
\text { Management applied to } \\
\text { road operations, by } \\
\text { PIARC }\end{array}$ & - & $\begin{array}{c}\text { Technical } \\
\text { Commitee } \\
1.5 \text { Risk } \\
\text { Management } \\
\text { World Road } \\
\text { Association } \\
\text { [12]. }\end{array}$ \\
\hline 2017 & $\begin{array}{c}\text { Risk Analysis of } \\
\text { Infrastructure Networks in } \\
\text { Response to Extreme } \\
\text { Weather }\end{array}$ & RAIN & $\begin{array}{l}\text { http://rain- } \\
\text { project.eu/ }\end{array}$ \\
\hline
\end{tabular}

RIMAROCC's methodology is a cyclical methodology with continuous improvement. It starts with the study of the context and continues with the identification, analysis, evaluation and mitigation of the risk, finishing with the implementation of the actions and their monitoring.

It requires a broad knowledge of the area where the study is applied, to know the different scenarios in relation to future $\mathrm{CC}$ and to know how to define and evaluate each of the risks. 
CAPRA's methodology is based on probabilistic evaluation of natural risks. It enables us to know the possible scenarios of the different threats to which a territory is subjected, thus serving as a tool for risk management policies. Analyzing the area affected by the risk establishes a cost associated to each of the risks.

The probabilistic methodology analyzes the threats of earthquake, flood, landslide and hurricanes. However, it does not analyze the damage associated with the increase in the temperature in the infrastructures or the periods of intense rains. Although the methodology is of great relevance, it cannot be applied to all natural and climatic risks that affect the infrastructures.

The project MOWE-IT analyzes the different transport systems from an economic point of view. Specifically for highways, the most probable impacts are indicated analyzing the possible consequences and the losses that they would cause. However, it does not evaluate possible $\mathrm{CC}$ scenarios or analyze in a specific way each of the associated problems that may occur. Neither does it allow the choice of the most appropriate measure to minimize the impact or increase the resilience of the infrastructure.

ROADAPT integrates the RIMAROCC project, and goes further, using a GIS application for the analysis.

This methodology includes new risks associated with $\mathrm{CC}$ and possible measures to be adopted, determining complete action plans. This tool is useful to perform any analysis and to do a complete study of the vulnerability of each of the infrastructures.

PIARC proposed in 2010 a general risk analysis approach and published the associated tool in its website in 2016. This methodology is based on a risk matrix that takes into account the times that the unwanted event has occurred and the consequences. It enables a generic initial study, but it does not allow the selection of the measures that mitigate the damages or the solutions that increase the resilience of the infrastructures.

RAIN has developed a Bayesian network for risk assessment. It analyzes and quantifies the interaction between the different infrastructures before an undesired natural hazard. In addition, the project also studies the individual danger and the cascade effect it may have.

This project is currently being carried out and it will propose measures to increase the resilience of infrastructure to natural hazards.

\section{IV.2. Recommendations}

To be able to adopt measures that minimize the damage associated with climate risks in roads, it is necessary to validate the tools presented for each case.

However, the decision-making regarding measures to be taken to minimize damage, is not decided yet.

Research is currently focused on the study of multihazard scenarios, as many of the projects and tools tend to focus on only one risk and it is known that a linear infrastructure may be subject to several climatic risks, each one with different magnitudes.
The ROADAPT project's highlight is that a method of vulnerability analysis has been developed. The project is focused on the analysis of the cause, effect and consequences of time-related events. It seeks to identify the main risks and proposes mitigation measures for adaptation to climate change including proactive, prevention, preparation, response and recovery measures.

The project proposes guidelines on how to carry out the evaluation and proposes mitigation measures, but there is no evaluation and study of the different corrective measures to be applied during the maintenance phase.

PIARC proposes an identification of damages by assets; that is to say, the variables on which the road resilience depends are: reliability (in the use of infrastructure), property (physical elements that constitute the infrastructure and can be damaged), personnel (road users and workers), financial (operation and road transport capacity) and environment (environmental impact associated with the operation of the road). PIARC proposed a system to evaluate the risks of damage to the road installations. The proposal is based on a risk matrix that allows an evaluation, but whose tool does not enable advice to be given to the companies or administrations responsible for the maintenance of the infrastructures, to select the most appropriate measure to mitigate the damages and / or to increase the resilience of the infrastructure to these threats.

Given the climatic risks, the maintenance of infrastructures in proper conditions should be a goal to increase the resilience to these events. Society cannot afford the rebuilding of 20-year-old infrastructures constructed with a lifespan of 100 years. This entails a very high economic, environmental and even social waste.

\section{Conclusion}

Infrastructures are vital systems for the development of society. The developed countries aim at the conservation and maintenance of these in adequate function for the population, increasing resilience to adverse climate events. Most of the infrastructures are already built, which has motivated the study of the new risks, not previously considered, and the need to develop actions to increase their resilience while operating.

The objective of the activities carried out during the exploitation phase, in addition to maintaining the infrastructure in an adequate state, should pursue the increase in resilience to the climatic risk. Resilient measures would also increase environmental sustainability within the construction sector.

All this should promote an improvement in the economic and environmental management in the exploitation phase, thus improving the integral management of the infrastructures. Consequently, it is necessary to validate a methodology of analysis of climatic risks, but also to facilitate the decision making on the measures to be established for raising resilience. 


\section{Acknowledgements}

The authors would like to thank the support to this research line given by ACCIONA Construcción, the leader of the Work Package 2 "Resilience to climate change" of REPARA 2.0, an industrial research and experimental development project carried out with the financial support of the CDTI (Centre for Technological and Industrial Development) within the call CIEN of the Ministry of Economy and Competitiveness of Spain.

\section{References}

[1] ISO Guide 73:2009, Risk management - Vocabulary. Technical Committee: ISO/TMBG Technical Management Board - groups, Edition 1, November 2009.

[2] UNISDR, Disaster Risk Reduction in the United Nations. Roles, mandates and results of key UN entities. UNISDR/GE/2013/4 ICLUX - V2 -1,500. 2013.

[3] E. Pellicer Armiñana, A. Alshubbak, J. Catalá Alís, Towards a systemic view of the life cycle of infrastructure [Hacia una visión sistémica del ciclo de vida de la infraestructura], Revista de Obras Públicas, Vol. 3532: 41-48, 2012.

[4] R. Mulcahy, Risk management. Tricks of the Trade for project managers and PMI-RMP exam prep guide: a course in a book, RMC Publications. Second ed. Minnetonka, Minnesota. 2010.

[5] PMI (Project Management Institute), Guide to the fundamentals for project management (PMBOK guide) [Guía de los fundamentos para la dirección de proyectos (guía del PMBOK)]. Project Management Institute, Inc. Newtown Square Ed. 5. Pennsylvania, 2013.

[6] W. Orabi, Y. Zhu, G. Ozcan-Deniz., Minimizing greenhouse gas emissions from construction activities and processes, Construction Research Congress 2012, West Lafayette, Indiana, United States, May 21-23, 2012. https://doi.org/10.1061/9780784412329.187

[7] K. A. Hossain, B. Gencturk, Life-Cycle Environmental Impact Assessment or Reinforced Concrete Buildings Subjected to Natural Hazards. Journal of Architectural Engineering, Vol. 22 (Issue 4), December 2014, ISSN 1076-0431/A4014001(12). doi: 10.1061/(ASCE)AE.1943-5568.0000153

[8] F. Böhle, E. Heidling, Y. Schoper, A new orientation to deal with uncertainty in projects. International Journal of Project Management, Vol. 34: 1384-139, 2016.

[9] PIARC, Study on risk management for roads, Technical Committee 18 Risk Management for Roads, 2005. ISBN: 284060-178-8.

[10] PIARC, Managing risk in road organization, Technical Committee C.3 Managing operational risk in national and international road operations, 2012.

[11] PIARC, Risks associated with natural disasters, climate change, man-made disasters and security threats, Technical Committee C.3 Managing operational risk in national and international road operations, 2013.

[12] M. Kidnei, A. Marchese, C. Maruntu, H. Murphy, R. Sebille, S. Thomson, C. Toplis, International climate change adaptation framework for road infrastructure, PIARC 2015.

[13] Z. Zhipeng, G. Yang Miang, L. Qiming, Overview and analysis of safety management studies in the construction industry, Safety Science, Vol. 72: 337-350, February 2015.

[14] Z. Lounis, T. McAllister, Risk-Based Decision Making for Sustainable and Resilient Infrastructure Systems, Journal of Structural Engineering, Vol. 142 (Issue 9), September 2016, F4016005. doi: 10.1061/(ASCE)ST.1943-541X.0001545

[15] Munich RE (Munich Reinsurance Company), Year of the floods, Topics GEO, Natural catastrophes (Issue Analyses, assessments, positions 2017), 2016.

[16] EM-DAT (Emergency Events Database), The International Disaster Database, Centre for Research on the Epidemiology of Disasters (CRED) 2017. http://www.emdat.be/ 2017

[17] S. C. Herring, M. P. Hoerling, J. P. Kossin, T. C. Peterson, P. A. Stott, Explaining extreme events of 2014 from a climate perspective. Bulletin of the American Meteorological Society. December, Vol. 96 (Issue 12), 2015.

[18] EEA (European Environmental Agency), Climate change adaptation, EEA, May 2017

[19] T. Giordano, Adaptive planning for climate resilient long-lived infrastructures, Utilities Policy. Vol. 23: 80-89, 2012.

[20] UNISDR, Terminology on Disaster Risk Reduction. International Strategy for Disaster Reduction [Terminología sobre Reducción del Riesgo de Desastres. Estrategia Internacional para la Reducción de Desastres de las Naciones Unidas], Ginebra, Suiza. May 2009K.

[21] S. Hudson, D. Cormie, E. Tufton, S. Inglis, Engineering resilient infrastructure, Proceedings of the Institution of Civil Engineers: Civil Engineering, Vol. 165 (Issue 6): 5-12, 2012.

[22] J. K. Buffenbarger, Building Toward a Sustainable and Resilient Future, Special Publication. Vol. 305: 26.1:26.16, 2015.

[23] D. Blockley, J. Agarwal, P. Godfrey, Infrastructure resilience for high-impact low-chance risks, Proceedings of the Institution of Civil Engineers: Civil Engineering Vol. 165 (Issue 6): 13-19, 2012.

[24] UNDP, Goal 9: Industry, innovation, infrastructure. United Nations Development Programme in Latinamerica and Caribe, Sustainable Development Goals, 2015,

http://www.latinamerica.undp.org/content/rblac/es/home/post2015/sdg-overview/goal-9.html.

[25] The World Bank, Building resilience. Integrating climate and disaster risks into development, The World Bank Group Experience, 2013,

http://documents.worldbank.org/curated/en/76287146814850617 3/pdf/826480WP0v10Bu0130Box37986200OUO090.pdf

[26] J. Abhas, T. W. Miner, Z. Stanton-Geddes, Building Urban Resilience: Principles, Tools, and Practice. Directions in Development, World Bank. Washington DC, 2013.

doi:10.1596/978-0-8213-8865-5 https://www.eea.europa.eu/themes/climate-change-adaptation

[27] FAO and OECD, Building resilience for adaptation to climate change in the agriculture sector. Proceedings of a Joint FAO / OECD Workshop 23-24 April, 2012.

http://www.fao.org/docrep/017/i3084e/i3084e00.htm

[28] USGCRP, US Climate Resilience Toolkit, United States Global Change Research Program. NOAA's Climate Program Office, 2017 https://toolkit.climate.gov/.

[29] Ministry of Agriculture, Food and Environment [Ministerio de Agricultura, Alimentación y Medio Ambiente], National Plan for Adaptation to Climate Change [Plan Nacional de Adaptación al Cambio Climático], Spanish Office of Climate Change [Oficina Española de Cambio Climático], Ministry of the Environment [Secretaría de Estado de Medio Ambiente]. Third Program of Work 2014-2020 [Tercer Programa de Trabajo 2014-2020]. January 2014.

[30] I. Tumini, C. Rubio-Bellido, Measuring Climate Change Impact on Urban Microclimate: A Case Study of Concepción, World Multidisciplinary Civil Engineering-Architecture-Urban Planning Symposium 2016, WMCAUS 2016, Procedia Engineering, Vol. 161, pp. 2290-2296, 2016.

[31] J. L. Fan, Q. M. Liang, X. J. Liang, H. Tatano, Y. Kajitani, Y.M. Wei, National vulnerability to extreme climatic events: the cases of electricity disruption in China and Japan, Nat Hazards. Vol 71:1937-1956, 2013. doi 10.1007/s11069-013-0986-2.

[32] M. Hulbert, J. Gupta, The adaptive capacity of institutions in Canada, Argentina, and Chile to droughts and floods, Regional Environmental Change, Vol. 17 (Issue 3): 865-877, March 2016, doi 10.1007/s10113-016-1078-0.

[33] P.Y. Wen-Huei, Earthquake! Federal Highway Administration, U.S. Department of Transport, FHWA-HRT-10-006, Vol. 74 (Issue 2), September-October 2010.

[34] P. Saarikivi, T. Gustavsson, D. Rayner, Final Report. IRWIN. Improved local winter index to assess maintenance needs and adaptation costs in climate change scenarios. Project $\mathrm{Nr}$. TR80A 
2008:72539. 2010.

http://ewent.vtt.fi/Documents/Reports/ENR_SRO3_IRWIN_Final Report_V1.pdf

[35] B. Klein, B. Gnandt, I. Lingemann, T. Prozny, G. Szépszó. Deliverable 1.2, Definition of climate change scenarios, ECCONET (Effects of climate change on the inland waterway transport network), Contract number 233886 - FP7. December 2010.

http://www.tmleuven.be/project/ecconet/ECCONET_D1.2_final.p df

[36] C. Matulla, B. Hollósi, J. Namyslo, Design guideline for a transnational database of downscaled climate projection data for road impact models- CliPDaR. CEDR Transnational ROAD research programme Call 2012, 2014.

[37] UTRC, An Agent-Based Disaster Response Inference Model for Assessment of Transportation Risk under Extreme Events. University Transportation Research Center, 2015. http://www.utrc2.org/research/projects/agent\%E2\%80\%90baseddisaster-response.

[38] S.B. Miles, S.E. Chang, ResilUS-Modeling community capital loss and recovery, The 14th World Conference on Earthquake Engineering, Beijing, China, 12-17 October 2008.

[39] HUXLEY College of the Environment, ResilUS: Modeling community recovery from disasters, Western Washington University, Accessed 3 February 2017 https://huxley.wwu.edu/ri/resilus

[40] Transportation Research Board, Costing Asses Protection: An All Hazards Guide for Transportation Agencies (CAPTA), National Cooperative Highway Research Program. Report 525, Vol. 15. Project 20-59 (Topic 17), 2009.

[41] Transportation Research Board, Interactive Training for AllHazards Emergency Planning, Preparation, and Response for Maintenance and Operations Field Personnel, National Cooperative Highway Research Program. Synthesis 468, Project 20-05(Topic 44-12) 2015, ISBN 978-0-309-27158-5.

[42] P. Leviäkangas, P. Saarikivi. D6: European Extreme Weather Risk Management - Needs, Opportunities, Costs and Recommendations. Work-Package WP6, 2012. http://ewent.vtt.fi/

[43] Federal Emergency Management Agency, Hazus Software. U.S. Department of Homeland Security, Accessed 4 May 2017. https://www.fema.gov/hazus-software

[44] UTRC, Metrics and Performance Response Functions for Assessment of Resilience of Urban Infrastructure Systems, University Transportation Research Center, $2012 a$. http://www.utrc2.org/research/projects/metrics-and-performanceresponse-functions.

[45] UTRC. A GIS-based Performance Measurement System for Assessing Transportation Sustainability and Community Livability, University Transportation Research Center, $2012 b$. http://www.utrc2.org/research/projects/GIS-based-performancemeasurement-system.

[46] UTRC, Analysing Willingness to Improve the Resiliency of New York City's Transportation System, University Transportation Research Center, 2014. http://www.utrc2.org/research/projects/improving-resiliency-ofnew-york-city-transportation-system.

[47] Iowa State University, Data-Driven Highway Infrastructure Resilience. Institute for Transportation. Accessed 8 January 2017. http://www.intrans.iastate.edu/mtc/index.cfm/research/project/pro ject/377096323

[48] PIARC, Towards development of a risk management approach, Technical Committee 3.2 Risk management for roads, 2010, ISBN: 2-84060-230-X.

\section{Authors' information}

${ }^{1}$ University of Cantabria, Spain.

${ }^{2}$ Ministry of Development, Spain.

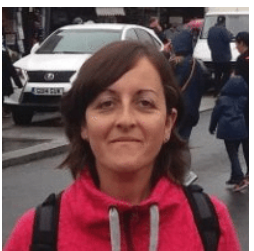

Sara Sanchez-Matellanes, Spain, May 17 1981. Master in environmental engineering and civil engineering, by University of Cantabria, Spain, 2011. She is doing her thesis in the field of civil engineering and environment. Ms. Sanchez-Matellanes collaborates with the department of GITECO research group.

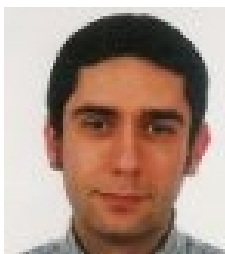

Jorge Rodriguez-Hernandez, Spain, June 23 1978. PhD Civil Engineering, by University of Cantabria, Spain, 2008. He has written different articles related to sustainable construction, the execution and conservation of roads and the use of renewable energy in construction sector. Dr. Prof. Rodriguez-Hernandez teaches at the of GITECO research group.

University of Cantabria and is the vice principal

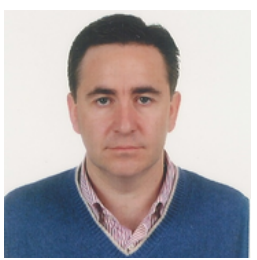

Daniel Castro-Fresno, Spain, January 021971. $\mathrm{PhD}$ Civil Engineering, by University of Cantabria, Spain, 2008. He has written different articles related to construction materials, sustainability and civil engineering. Dr. Prof. Castro-Fresno teaches at the University of Cantabria and is the director of GITECO research group.

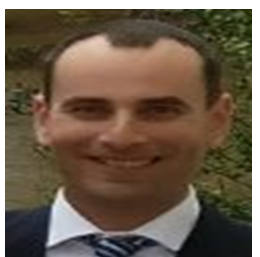

Felipe Collazos-Arias, Spain, March 121978 $\mathrm{PhD}$ Civil Engineering, by University of Extremadura, Spain, 2012. He has written articles related to construction's risks and construction sector. Dr. Collazos-Arias works at Ministry of Development; his work is related to road risks. 